\title{
In vitro fermentability of xylo- oligosaccharide and xylo-polysaccharide fractions with different molecular weights by human faecal bacteria
}

Article

Accepted Version

Creative Commons: Attribution-Noncommercial-No Derivative Works 4.0

Ho, A. L., Kosik, O., Lovegrove, A., Charalampopoulos, D. and Rastall, R. A. (2018) In vitro fermentability of xylooligosaccharide and xylo-polysaccharide fractions with different molecular weights by human faecal bacteria. Carbohydrate Polymers, 179. pp. 50-58. ISSN 0144-8617 doi: https://doi.org/10.1016/j.carbpol.2017.08.077 Available at https://centaur.reading.ac.uk/73126/

It is advisable to refer to the publisher's version if you intend to cite from the work. See Guidance on citing.

To link to this article DOI: http://dx.doi.org/10.1016/j.carbpol.2017.08.077

Publisher: Elsevier

All outputs in CentAUR are protected by Intellectual Property Rights law, including copyright law. Copyright and IPR is retained by the creators or other copyright holders. Terms and conditions for use of this material are defined in the End User Agreement. 


\section{www.reading.ac.uk/centaur}

\section{CentAUR}

Central Archive at the University of Reading

Reading's research outputs online 
1 In vitro fermentability of xylo-oligosaccharide and xylo-polysaccharide fractions with

4 Ai Ling $\mathrm{Ho}^{\mathrm{a}, 1}$, Ondrej Kosik ${ }^{\mathrm{b}}$, Alison Lovegrove ${ }^{\mathrm{b}}$, Dimitris Charalampopoulos ${ }^{\mathrm{a}}$, Robert A.

$5 \quad$ Rastall $^{\mathrm{a}^{*}}$

6

$7 \quad{ }^{a}$ Department of Food and Nutritional Sciences, University of Reading, Whiteknights, P.O.

8 Box 226, Reading RG6 6AP, United Kingdom.

$9{ }^{\mathrm{b}}$ Centre for Crop Genetic Improvement, Dept. of Plant Biology and Crop Science,

10 Rothamsted Research, Harpenden, Herts AL5 2JQ, United Kingdom.

11

12 *Corresponding author (Tel.: +44 (0)118 378 6726; Fax: +44 (0)118 931 0080)

13

14 E-mail addresses: alho@ums.edu.my (A.L. Ho), ondrej.kosik@rothamsted.ac.uk (O. Kosik),

15 alison.lovegrove@ rothamsted.ac.uk (A. Lovegrove), d.charalampopoulos@ reading.ac.uk (D.

16 Charalampopoulos), r.a.rastall@ reading.ac.uk (R. A. Rastall)

17

$18{ }^{1}$ Present/permanent address: Faculty of Food Science and Nutrition, Universiti Malaysia

19 Sabah, Jalan UMS, 88450 Kota Kinabalu, Sabah, Malaysia. 


\section{Abstract}

23 Xylo-oligosaccharides and xylo-polysaccharides (XOS, XPS) produced by autohydrolysis

24 of the fibre from oil palm empty fruit bunches (OPEFB) were purified using gel filtration

25 chromatography to separate the XOS and XPS from the crude autohydrolysis liquor. Six

26 mixed fractions of refined XOS and XPS with average degree of polymerisation (avDP) of

27 4-64 were obtained. These were characterised in terms of their composition and size by

28 HPLC, MALDI-ToF-MS (selected fractions) and carbohydrate gel electrophoresis (PACE).

29 They were assessed in batch culture fermentations using faecal inocula to determine their

30 ability to modulate the human faecal microbiota in vitro by measuring the bacterial growth,

31 organic acid production and the XOS assimilation profile. The gut microbiota was able to

32 utilise all the substrates and there was a link between the XOS/XPS degree of

33 polymerisation with the fermentation properties. In general, XOS/XPS preparations of

34 lower avDP promote better Bifidobacterium growth and organic acid production.

\section{Keywords}

37 Autohydrolysis; in vitro fermentation; Oil palm empty fruit bunches; Xylo-oligo and xylo38 polysaccharides

\section{Introduction}

The benefits of non-digestible oligosaccharides (NDOs) in modulating the intestinal

42 and colonic microbiota that have an effect on human gut health have been well established

43 and the study of NDOs derived from plant cell walls as emerging prebiotics has raised

44 much interest. This is because plant cell walls, especially derived from cereal grains, are 
45 part of our dietary fibre intake; the particular components of plant cell walls of interest in

46 the context of prebiotics are the hemicelluloses. Hemicelluloses are the second most

47 abundant class of polysaccharides available in the plant kingdom with xylan being the most

48 common. Xylans have a backbone of $\beta-(1 \rightarrow 4)$ linked xylose units that are often substituted

49 with arabinose, methylated or non-methylated glucuronic acid, acetic acid or ferulic acid

50 (Ebringerová, Hromadkova \& Heinze, 2005). Thus, depending on the origin of the plant

51 cell wall and treatment process, various xylo-oligosaccharides (XOS, avDP $\leq 20)$ or xylo-

52 polysaccharides (XPS, avDP > 20) with or without branching can be obtained.

53 In this regard, plant lignocellulosic biomass generated at the agricultural field and

54 processing plant, which was once considered as waste for disposal, offers an enormous

55 potential resource as a basic feedstock for XOS production (Moure, Gullón, Domínguez \&

56 Parajó, 2006). In the context of biorefining, hydrothermal treatments such as autohydrolysis

57 have been investigated as an initial step of a possible multi-stage process for the utilisation

58 of lignocellulosic materials, as it can produce soluble oligosaccharides, leaving cellulose

59 and lignin in the solid phase for other usage (Parajó, Garrote, Cruz \& Domínguez, 2004).

60 The XOS obtained from autohydrolysis treatment also retain some substituents that are

61 present in the native xylan such as acetyl groups, which could have an effect on their

62 fermentability by the human intestinal microbiota (Kabel, Schols \& Voragen, 2002b).

63 Earlier studies on the ability of XOS to modulate the intestinal microbiota

64 investigated linear XOS of small molecular weight with a DP around 2-3. The low

65 molecular weight XOS significantly promoted the growth of bifidobacteria and led to an

66 increase in short chain fatty acid (SCFA) production in the bacterial cultures (Crittenden et 
67 al., 2002; Okazaki, Fujikawa \& Matsumoto, 1990; Palframan, Gibson \& Rastall, 2003a)

68 and in in vivo studies in humans and animals (Campbell, Fahey \& Wolf, 1997; Childs et al.,

69 2014; Chung, Hsu, Ko \& Chan, 2007). Pure culture studies using XOS from corn cob and

70 rice husk autohydrolysis with $\mathrm{DP} \leq 4$ also enhanced the growth of bifidobacteria despite

71 having some acetyl groups and/or uronic acid substituents (Gullón et al., 2008; Moura et

72 al., 2007). In Kabel, Kortenoeven, Schols \& Voragen (2002a), a XOS preparation with

73 wider range mixed DP (DP 2-11) was used and when fermented in vitro with human faecal

74 inocula, the substrate was almost completely degraded in $20-40 \mathrm{~h}$ of fermentation. The

75 fermentation rate and the SFCA profiles however varied depending on the substituents that

76 were present, whereby the linear XOS and arabinose substituted XOS (AXOS) were

77 fermented faster than acetylated XOS and methylglucuronylated XOS was the slowest. The

78 bacteriology profile however was not the focus in that study, so the way the substituents

79 modulate the gut microbiota is unknown. Increases in potentially health-positive bacterial

80 groups such as Bifidobacterium spp. and Lactobacillus/Enterococcus spp. were seen with

81 high average molecular weight arabinoxylans of 66,278 and $354 \mathrm{kDa}$ (Hughes, Shewry, Li,

82 Gibson, Sanz \& Rastall, 2007). However, the arabinoxylans tested also significantly

83 promoted clostridial growth. Van Craeyveld (2008) in a more systematic study on the

84 influence of the average degree of polymerisation (avDP) and average degree of arabinose

85 substitution (avDAS) of XOS preparation in the cecum of rats, showed that low molecular

86 weight AXOS (avDP-avDAS of 5-0.27 and 3-0.26) increased Bifidobacterium spp.

87 significantly more than high molecular weight AXOS (avDP -avDAS of 61-0.58). On the

88 other hand, the measured branched SCFA was the lowest with avDP 61, so this could

89 potentially suppress the metabolites from protein fermentation. 
In a previous study, results have demonstrated that it is possible to produce purified

91 XOS fractions of a variety of avDP from oil palm biomass autohydrolysis liquor (Ho et al.,

92 2014). The aim of this work was to study the effect of XOS and XPS obtained from

93 purification of autohydrolysed OPEFB at different avDP 4-64 upon the gut microbiota

94 population. The rationale for inclusion of higher avDP XOS/XPS preparations in this study

95 is they may have better persistence into the distal colon, with potential benefits to chronic

96 gut diseases.

97

98 2. Materials and methods

$99 \quad 2.1$ Preparation of XOS/XPS fractions

100 The XOS/XPS preparation was according to Ho et al. (2014). Briefly, the fibre of

101 dried oil palm empty fruit bunches (OPEFB) was subjected to non-isothermal

102 autohydrolysis treatment in a two litre capacity stainless steel reactor (Parr Instruments Co.,

103 llinois, United States) with an operational temperature $210{ }^{\circ} \mathrm{C}$ and a liquid to solid ratio of 8

104 (w/w). The liquor obtained from autohydrolysis treatment was filtered and purified using

105 preparative gel filtration chromatography (GFC) (Ho et al., 2014) with a BPG 100/950

106 column filled with Superdex $30^{\mathrm{TM}}$ (Amersham Pharmacia Biotech, Uppsala, Sweden). The

107 liquid fractions were freeze dried and then pooled together to obtained six mixed freeze-

108 dried XOS/XPS with a range of avDP.

109

1102.2 Characterization of XOS/XPS fractions 
111 Prior to the determination of average molar mass and chemical compositions, the

$112 \mathrm{XOS} / \mathrm{XPS}$ samples were dissolved in deionised water to obtain a concentration of $10 \mathrm{~g} / \mathrm{L}$.

113 The apparent molar mass of samples was determined by high performance liquid

114 chromotography (HPLC) (Agilent 1100 series, Winnersh, UK). A size exclusion column

115 BIOSEP-SEC S2000 (Phenomenex, Cheshire, UK) was used at $30{ }^{\circ} \mathrm{C}$ with $50 \mathrm{mM} \mathrm{NaNO}_{3}$

116 as mobile phase at $0.7 \mathrm{~mL} / \mathrm{min}$. The eluate was detected using a refractive index (RI)

117 detector. External standards with different molecular weights, i.e. xylose,

118 maltooligosaccharides (DP 2-5) and dextrans (1-71 kDa, Sigma, Dorset, UK) were used for

119 calibration.

120 The composition of the XOS/XPS samples was assayed by HPLC to quantify free

121 monosaccharides (glucose, xylose and arabinose), aliphatic acids (acetic acid, formic acid

122 and levulinic acid) and furan derivatives (furfural and 5-hydroxymethylfurfural, HMF)

123 compounds. An Aminex HPX-87H column (BioRad, Hemel Hempstead, UK) was used at

$12450{ }^{\circ} \mathrm{C}$ with $5 \mathrm{mM} \mathrm{H}_{2} \mathrm{SO}_{4}$ as mobile phase. The monosaccharides and aliphatic acids were

125 detected with a RI detector while furfural and HMF were detected using a diode array

126 detector (DAD) at $280 \mathrm{~nm}$.

127 The oligosaccharide content was determined by an indirect method using

128 quantitative acid hydrolysis; this was done by mixing the XOS/XPS sample with $\mathrm{H}_{2} \mathrm{SO}_{4}$

$129(72 \% \mathrm{w} / \mathrm{w})$ to obtain a final acid concentration of $4 \%(\mathrm{w} / \mathrm{w})$ and the sample was heated at

$130121{ }^{\circ} \mathrm{C}$ for $60 \mathrm{~min}$ to induce hydrolysis. The post hydrolysed liquor was analysed with

131 HPLC and the oligosaccharide concentration was expressed as the increase in sugar

132 monomers (Sluiter et al., 2006). 
134 method using gallic acid as standard (Singleton \& Rossi, 1965).

\subsection{MALDI-Tof-MS of XOS fractions}

MALDI-ToF-MS was used to analyse the extracted OPEFB XOS fractions in native

138 and permethylated form for XOS avDP 4, 7 and 14. Initial analysis of the native fractions

139 did not produce strong signals (Figure S1) so analyses were also performed with

140 permethylated fractions. Permethylation of XOS fractions was performed using the

$141 \mathrm{NaOH} / \mathrm{DMSO}$ slurry method using $0.5 \mathrm{~mL}$ of methyl iodide (Ciucanu \& Kerek, 1984).

142 Permethylated glycans were dried under a stream of nitrogen and re-dissolved in $100 \mu \mathrm{L}$ of

143 methanol. Five $\mu \mathrm{L}$ of native or permethylated XOS fractions $(10 \mathrm{mg} / \mathrm{mL})$ were mixed with

$1445 \mu \mathrm{L}$ of 2, 5-dihydroxybenzoic acid (DHB, $10 \mathrm{mg} / \mathrm{mL}$ dissolved in $50 \% \mathrm{MeOH}$ with $1 \%$

145 TFA, v/v) matrix. One $\mu \mathrm{L}$ of native or permethylated glycans mixed with DHB matrix was

146 spotted onto a MALDI target plate and allowed to air-dry. MALDI-ToF-MS was carried

147 out using a Micromass MALDI-LR mass spectrometer (Waters, Manchester, UK) using a

148 mass acquisition between $\mathrm{m} / \mathrm{z} 450$ and 3 000. The MALDI set-up was as described by

149 Marsh et al. (2011). Glycan adduct ions $[\mathrm{M}+\mathrm{Na}]^{+}$were assigned. Experimentally

150 determined masses were interpreted using GlycoMod (ExPaSy).

151

1522.4 Analysis of XOS/XPS fractions by carbohydrate gel electrophoresis

Polysaccharide Analysis by Carbohydrate Gel Electrophoresis (PACE) was used to 154 analyse the extracted OPEFB XOS/XPS fractions. Fractions were run with and without 
155 digestion with xylanase 11. Briefly, for xylanase digested samples, $200 \mu \mathrm{g}$ aliquots were 156 digested with Xyn11 (4 $\mu \mathrm{L} \approx 21.92 \mu \mathrm{g}$; Prozomix, UK) for $16 \mathrm{~h}$ at $40{ }^{\circ} \mathrm{C}$ in total volume of $157500 \mu \mathrm{L}$. Digestion was terminated by boiling the samples for $30 \mathrm{~min}$ and samples were 158 dried in vacuo. Aliquots $(200 \mu \mathrm{g})$ of undigested XOS/XPS fractions were also dried down. 159 All samples together with standard xylo-oligosaccharides (Xyl1-6; Megazyme, Ireland) were 160 labelled with ANTS and ran on acrylamide gel as described by Kosik, Bromley, Busse161 Wicher, Zhang \& Dupree (2012). Gels were visualized under UV light using a GelDoc-It 162 TS2 imager (UVP, Germany) equipped with a GFP emission filter (513-557 nm).

1642.5 In vitro batch fermentation The six different fractions of XOS/XPS along with commercial XOS (avDP2,

166 Shandong Longlive Biotechnology Co. Ltd (SLBC), China) and birch wood xylan (Sigma, 167 Dorset, UK) were evaluated for the ability to modulate the gut microbiota using an in vitro 168 batch culture fermentation system inoculate with human faecal sample.

169 Fructooligosaccharides (avDP 4, Raftilose ${ }^{\circledR}$, Orafti, Tienan, Belgium) were used as the 170 positive control. The in vitro fermentation was carried out a $50 \mathrm{~mL}$ working volume glass 171 jacketed bioreactors, sterile of stirred batch culture fermentation system. The carbohydrates 172 sources were added at $1 \%(\mathrm{w} / \mathrm{v})$. The basal medium (per litre) consisted of: $2 \mathrm{~g}$ peptone 173 water, 2 g yeast extract, $0.1 \mathrm{~g} \mathrm{NaCl}, 0.04 \mathrm{~g} \mathrm{~K}_{2} \mathrm{HPO}_{4}, 0.04 \mathrm{~g} \mathrm{KH}_{2} \mathrm{PO}_{4}, 0.01 \mathrm{~g} \mathrm{MgSO} 4.7 \mathrm{H}_{2} \mathrm{O}$, $1740.01 \mathrm{~g} \mathrm{CaCl} 6 \mathrm{H}_{2} \mathrm{O}, 2 \mathrm{~g} \mathrm{NaHCO}_{3}, 2 \mathrm{~mL}$ Tween 80, $0.05 \mathrm{~g}$ haemin, $0.01 \mathrm{~mL}$ vitamin $\mathrm{K}_{1}, 0.5$ $175 \mathrm{~g}$ L-cysteine- $\mathrm{HCl}, 0.5 \mathrm{~g}$ bile salt and $4 \mathrm{~mL}$ resazurin solution $(0.25 \mathrm{~g} / \mathrm{L})$. 
177 healthy human faecal donors, who had not taken prebiotic or probiotic products for 3

178 months, or antibiotics for six months prior to the study. Each vessel containing

179 fermentation medium was inoculated with $5 \mathrm{~mL}$ of faecal slurries, which was prior diluted

180 at $10 \%(\mathrm{w} / \mathrm{w})$ with anaerobic phosphate-buffered saline (PBS, $0.1 \mathrm{M})$ and homogenised in

181 a stomacher (Stomacher 400; Seward, West Sussex, UK) for 2 min at medium speed.

182 The fermentation was carried out at $\mathrm{pH}$ 6.7-6.9, controlled using an automated $\mathrm{pH}$

183 controller (Fermac 260; Electrolab, Tewkesbury, UK) and at $37{ }^{\circ} \mathrm{C}$ (using a

184 thermocirculator) under anaerobic atmosphere, which was achieved through continuous

185 sparging with nitrogen gas. Samples $(5 \mathrm{~mL})$ were taken from each fermentation vessel at 0 ,

18610,24 and $36 \mathrm{~h}$ for organic acid analysis and bacterial enumeration using the fluorescent in 187 situ hybridisation (FISH) technique.

2.6 Enumeration of bacteria

The target faecal bacteria groups were enumerated by FISH using 16S rRNA

191 targeted oligonucleotide probes labelled with the fluorescent Cy3 dye. An aliquot $(375 \mu \mathrm{L})$

192 of sample from each sampling time was mixed with 3 volumes of $4 \%$ (w/v) cold

193 paraformaldehyde (PFA) solution. The duration of fixation was $5-10 \mathrm{~h}$ at $4{ }^{\circ} \mathrm{C}$, followed by

194 centrifugation at $13000 \times g$ for $5 \mathrm{~min}$; the cell pellet was then washed twice with $1 \mathrm{~mL}$ cold 195 filter sterilised PBS. The washed cells were then resuspended in $150 \mu \mathrm{L}$ PBS and $150 \mu \mathrm{L}$ of 196 absolute ethanol and stored at $-20{ }^{\circ} \mathrm{C}$ until analysis. 
To further process the PFA-fixed sample, $10 \mu \mathrm{L}$ of each sample was diluted with

198 PBS/SDS (sodium dodecyl sulphate) diluent and the diluted samples (20 $\mu \mathrm{L})$ were applied 199 onto six-well of a polytetrafluoroethylene/poly--lysine coated slide (Tekdon Inc., Myakka 200 City, FL). The samples were dried at $48{ }^{\circ} \mathrm{C}$ for $15 \mathrm{~min}$ in a desktop plate incubator and then 201 dehydrated using a series of ethanol solution at 50\%, $80 \%$ and $96 \%$ (v/v) for 3 min each.

202 The excess ethanol was evaporated by drying the slides in a desktop plate incubator for 2 203 min followed by addition of $50 \mu \mathrm{L}$ of mixed hybridisation solution $(5 \mu \mathrm{L}$ oligonucleotide 204 probe solution and $45 \mu \mathrm{L}$ hybridisation buffer) onto each well. The slide with samples were 205 hybridised in a microarray hybridisation incubator (Grant-Boekel, Cambridge, UK) for $4 \mathrm{~h}$, 206 washed in $50 \mathrm{~mL}$ washing buffer for $15 \mathrm{~min}$ and dipped in cold distilled water for $2 \mathrm{~s}$.

207 Slides were dried with compressed air and a drop of PVA-DABCO antifade (polyvinyl 208 alcohol mounting medium with 1, 4-diazabicyclo (2.2.2) octane) was added onto each well. 209 The microscope cover slip was placed on each slide and the cell numbers of 210 microorganisms were determined by direct counting under an epifluorescence microscope 211 (Eclipse 400; Nikon, Surrey, UK) with Fluor 100 lens. A total of 15 fields of view were 212 counted for each well.

213 The probes used were Bif164 (Langendijk et al., 1995), Bac303 (Manz, Amann, 214 Ludwig, Vancanneyt \& Schleifer, 1996), Lab158 (Harmsen, Elfferich, Schut \& Welling, 215 1999), Ato291 (Harmsen, et al., 2000), Prop853 (Walker, Duncan, McWilliam Leitch, 216 Child \& Flint, 2005), Erec482 (Franks et al., 1998), Rrec584 (Walker et al., 2005), 217 Fprau655 (Hold, Schwiertz, Aminov, Blaut \& Flint, 2003), Chis150 (Franks et al., 1998), 218 and mixed Eub338 I, II, III (Daims, Brühl, Amann, Schleifer \& Wagner, 1999) for 219 enumerating Bifidobacterium spp., Bacteroides-Prevotella, Lactobacillus-Enterococcus, 
221 rectale-Clostridium cocoides group (Clostridium cluster XIVa and XIVb), Roseburia spp.,

222 Faecalibacterium prausnitzii cluster Clostridium histolyticum group (Clostridium cluster I

223 and II) and total bacteria, respectively.

\subsection{Organic acid analysis}

An aliquot $(1 \mathrm{~mL})$ of sample from each sampling time was centrifuged at $13000 \mathrm{xg}$

227 for $10 \mathrm{~min}$ and the supernatant was stored at $-20{ }^{\circ} \mathrm{C}$ until analysis. Organic acids analysis 228 was performed using an HPLC (1100 series; Agilent, Winnersh, UK) with refractive index

229 detection. Prior to the analysis, the samples, after thawing, were centrifuged at $13000 \times \mathrm{g}$

230 for $10 \mathrm{~min}$ and the supernatants were filtered through a $0.22 \mu \mathrm{m}$ filter unit. An ion

231 exclusion column, Rezex ROA-Organic Acid H+ (8\%) (Phenomenex, Cheshire, UK) was

232 used for the analysis, using $2.5 \mathrm{mM} \mathrm{H}_{2} \mathrm{SO}_{4}$ as eluent. The column was heated at $84{ }^{\circ} \mathrm{C}$ and

233 the eluent flow rate was set at $0.5 \mathrm{~mL} / \mathrm{min}$. The injection volume used was $20 \mu \mathrm{L}$ with 40

234 min run time. Organic acids were quantified using standard calibration curves for lactate, 235 acetate, propionate, butyrate and valerate at concentrations of 12.5, 25, 50, 75 and $100 \mathrm{mM}$.

236 Formate was determined using a formate dehydrogenase-based assay kit (Megazyme, 237 Ireland).

2392.8 Carbohydrate assimilation profile during fermentation 
242 Chromatography (HPAEC, Dionex, Camberley, UK) using a CarboPac PA-1 column and

243 Pulsed Amperometric Detection (PAD). Samples were filtered and diluted with deionised

244 water at a dilution factor of 30 . The injection volume was $25 \mu \mathrm{L}$ and the flow rate 1

$245 \mathrm{~mL} / \mathrm{min}$ with the following linear gradient: $8.75 \mathrm{mM} \mathrm{NaOH}$ and $2.4 \mathrm{mM}$ sodium acetate

246 from 0-19 $\mathrm{min} ; 30 \mathrm{mM} \mathrm{NaOH}$ and $25 \mathrm{mM}$ sodium acetate from 20-44 min; and $96.875 \mathrm{mM}$

$247 \mathrm{NaOH}$ and $150 \mathrm{mM}$ sodium acetate from 45-49 min. After 50 minutes, a washing step was

248 performed with $125 \mathrm{mM} \mathrm{NaOH}$ and $500 \mathrm{mM}$ sodium acetate for $10 \mathrm{~min}$ and the column

249 was then equilibrated for $20 \mathrm{~min}$ with $8.75 \mathrm{mM} \mathrm{NaOH}$ and $2.4 \mathrm{mM}$ sodium acetate.

250 Standard glucose, arabinose, xylose and xylose oligomers (DP 2-6, Megazyme, Ireland)

251 were used for identification.

252

$253 \quad 2.9$ Statistical analysis

254 Statistical analysis was performed using SPSS for Windows, version 17.0. One-way 255 analysis of variance (ANOVA) and Tukey's posthoc test was used to determine significant

256 differences among the bacterial group populations and organic acid concentrations among

257 the different substrates. A paired independent t-test was also used to determine significant

258 changes for each bacterial group concentration at inoculation and subsequent sampling

259 point. Differences were considered to be significant when $\mathrm{p}<0.05$.

260

\section{3. Results and discussion}

262 3.1 Characterization of the XOS/XPS fractions 
264 autohydrolysis liquor is shown in Table 1. In all cases, XOS/XPS were the dominant 


\section{Table 1}

Composition of OPEFB fibre fractions ( $\mathrm{g} / 100 \mathrm{~g}$ freeze dried sample) obtained after GFC purification ${ }^{\mathrm{a}}$

\begin{tabular}{|c|c|c|c|c|c|c|c|c|c|c|}
\hline \multirow[t]{2}{*}{$\begin{array}{c}\text { Sample } \\
\text { no. }\end{array}$} & \multirow[t]{2}{*}{$\mathrm{avDP}^{\mathrm{b}}$} & \multicolumn{4}{|c|}{ Residues in linkage (g/100 g) } & \multicolumn{2}{|c|}{ Ratio $^{c}$} & \multicolumn{2}{|c|}{$\begin{array}{l}\text { Free Monomers } \\
(\mathrm{g} / 100 \mathrm{~g})\end{array}$} & \multirow[t]{2}{*}{$\begin{array}{l}\text { Total phenolics } \\
\text { (g/100 g) }\end{array}$} \\
\hline & & Glc & Xyl & Ara & $\mathrm{AcO}$ & Ara/Xyl & $\mathrm{AcO} / \mathrm{Xyl}$ & Xylose & Acetic acid & \\
\hline 1 & 4 & 1.75 & 62.25 & 1.49 & 9.16 & 0.02 & 0.37 & 1.23 & 1.73 & 0.46 \\
\hline 2 & 7 & 1.62 & 65.38 & 1.16 & 10.30 & 0.02 & 0.39 & 0.86 & 0.80 & 0.37 \\
\hline 3 & 14 & 1.56 & 67.32 & 1.22 & 11.23 & 0.02 & 0.42 & 0.65 & 0.48 & 0.33 \\
\hline 4 & 28 & 1.61 & 67.68 & 1.18 & 12.43 & 0.02 & 0.46 & 0.57 & 0.46 & 0.31 \\
\hline 5 & 44 & 2.31 & 64.00 & 1.21 & 12.75 & 0.02 & 0.50 & n.d & 0.48 & 0.43 \\
\hline 6 & 64 & 2.83 & 59.28 & 1.16 & 12.95 & 0.02 & 0.55 & n.d & 0.46 & 0.43 \\
\hline
\end{tabular}

${ }^{\mathrm{a}}$ In freeze dried form and reconstitute with deionised water to give final concentration of $10 \mathrm{~g} / \mathrm{L}$. Calculations were made by assuming the freeze dried samples have $5 \%$ moisture content.

$\mathrm{b}_{\mathrm{avDP}}$ - Average degree of polymerization as determined by size exclusion chromatography

${ }^{\mathrm{c}}$ Ratio in $\mathrm{mol} / \mathrm{mol}$

AcO - acetyl groups linked to oligosaccharides; n.d. - not detected 
270 oligosaccharides, accounting for $78-83 \%$ of the total oligosaccharides. The highest

271 XOS/XPS yield was found in the middle fractions (avDP 14 and 28); free monomeric

272 compounds (xylose and acetic acid) were present at slightly higher concentrations in XOS

273 fractions with lower DP (avDP 4 and 7) than in the other fractions with free xylose absent

274 in XPS fractions with higher DP (avDP 44 and 64). The oligosaccharides of the higher DP

275 fractions (XPS, avDP 44 and 64) were more acetylated. The acetyl groups contribute to the

276 oligosaccharides solubility in water (Nabarlatz, Ebringerová \& Montané, 2007) and this

277 may be the reason that high molecular weight XOS fractions were present in OPEFB

278 autohydrolysis liquor. The arabinose content was rather low for all fractions, with an

279 arabinose to xylose ratio of approximating 0.02. The gluco-oligosaccharides (GlcOS) were

280 presumably derived from cellulose and were present at $2-3 \% \mathrm{w} / \mathrm{w}$. There was also a small

281 amount of total phenolic compounds $(<0.5 \% \mathrm{w} / \mathrm{w})$ found in all samples.

282 OPEFB fractions (avDP 4, 7 and 14) were analysed by MALDI-ToF-MS (larger

283 avDP fractions were too large for MALDI-ToF-MS analysis). XOS/XPS fractions were all

284 analysed in both their native and permethylated forms by MALDI-ToF-MS. All XOS/XPS

285 fractions analysed in their native form showed acetylated pentose oligosaccharide ions

286 (labelled Pent $\mathrm{Ac}_{\mathrm{n}}$, the ${ }_{\mathrm{n}}$ denoting the number of pentose (Pent) or acetyl (Ac) groups

287 respectively). In avDP 4 the most dominant ion is $m / z 917.27$ (Pent ${ }_{6} \mathrm{Ac}_{2}$ ) (Fig. 1) with

288 acetylated oligosaccharides ranging from $\mathrm{Pent}_{4} \mathrm{Ac}_{2}(\mathrm{~m} / \mathrm{z}, 653.19)$ to $\mathrm{Pent}_{9} \mathrm{Ac}_{4}(\mathrm{~m} / \mathrm{z}, 1397.42)$.

289 Also present are pentose oligosaccharides with no acetylation or other modifications with

290 DP 6 to $9(\mathrm{~m} / z, 833.25$ to 1229.38$)$ and hexose oligosaccharides of DP 4-8 $(\mathrm{m} / \mathrm{z}, 689.21$ to

291 1337.42). There could also be small pentose oligosaccharides with methylated-glucuronic

292 acid substitutions (ions at $\mathrm{m} / \mathrm{z} 637.18$ and 685.18 ) found in the native avDP 4 fraction. The 
293 permethylated version of avDP 4 fraction (data not shown); although the acetylated

294 residues of the pentose oligosaccharides are lost, we were able to see a pentose ladder

295 starting from Pent $3(\mathrm{~m} / z$ 549.25) up to Pent $9(\mathrm{~m} / \mathrm{z}$ 1509.69) and ladder of pentose

296 oligosaccharide substituted with single glucuronic acid up to DP $8\left(\mathrm{Pen}_{1} \mathrm{HexA}_{1}, m / z 447.18\right.$

297 to $\mathrm{Pen}_{7} \mathrm{Hex}_{1}, \mathrm{~m} / z$ 1407.63) that could not be observed in native form of the sample.

298 Similarly to the native version of avDP 4 XOS fraction hexose oligosaccharide ladder was

299 observed $\left(\operatorname{Hex}_{3} \mathrm{~m} / z\right.$ 681.33- Hex $8 \mathrm{~m} / z$ 1701.83) These data confirm the data in Table 1

300 which showed gluco-oligosaccharides (hexose oligosaccharides), xylo- and arabino-

301 oligosaccharides (pentose oligosaccharides) and acetylated oligosaccharides. Mass

302 spectrometry of OPEFB fractions of avDP 7 and avDP 14 also confirmed the data in Table

303 1. The predominant ions were the acetylated pentoses e.g. $\mathrm{m} / 2.785 .18\left(\mathrm{Pent}_{5} \mathrm{Ac}_{2}\right)$ up to

$304 \operatorname{Pent}_{9} \mathrm{Ac}_{5}$ ion $(\mathrm{m} / z$ 1439.43) and methylated glucuronic acid substituted oligosaccharides

305 were also present $(\mathrm{m} / \mathrm{z} 637.18$ and $\mathrm{m} / \mathrm{z}$ 685.18) (Supplementary Fig. 1a). The permethylated

306 avDP7 fraction (Supplementary Fig. 1b) also contained hexose oligosaccharides (Hex $4, \mathrm{~m} / \mathrm{z}$

307885.43 to $\mathrm{Hex}_{10} \mathrm{~m} / \mathrm{z} 2110.03$ ) as well as pentose oligosaccharide substituted with

308 glucuronic acid (Pent ${ }_{2} \mathrm{Hex}_{1}, m / z 607.26$ to Pent ${ }_{9} \mathrm{HexA}_{1}, m / z$ 1727.77). In OPEFB the

309 avDP 14 fraction (Supplementary Fig. 1c) acetylated pentose oligosaccharides range from

$310 \mathrm{Pent}_{5} \mathrm{Ac}_{2}, m / z, 785.23$ to $\mathrm{Pent}_{18} \mathrm{Ac}_{6}, m / z$ 2669.82. Also, observed in the permethylated

311 avDP14 (Supplementary Fig.1d) are glucuronic acid substituted pentoses, Pent ${ }_{3} \mathrm{Hex}_{1}(\mathrm{~m} / \mathrm{z}$

$312767.33)$ to Pent $_{13} \mathrm{HexA}_{1}(\mathrm{~m} / \mathrm{z}$ 2368.07). 


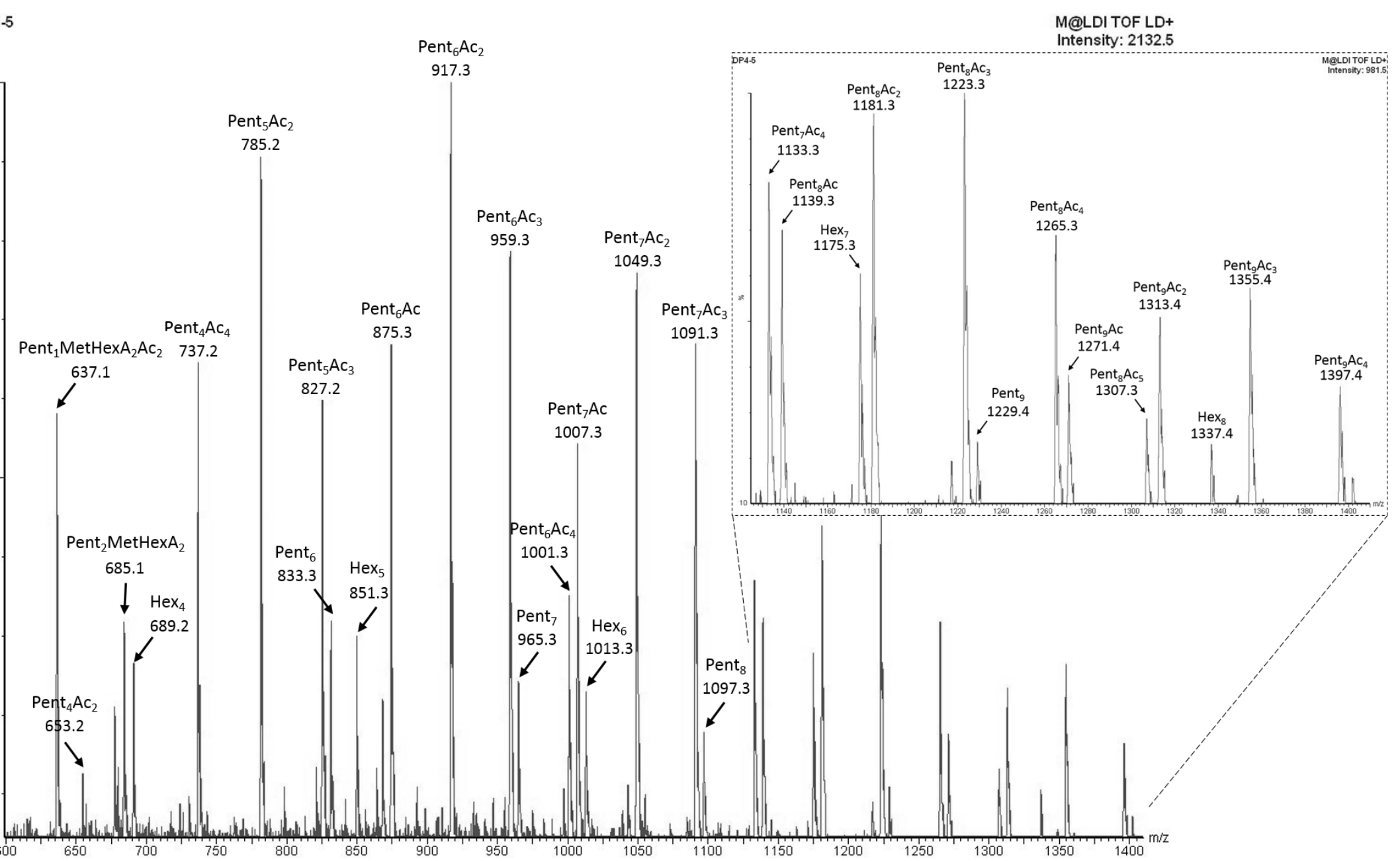

850

900

$1000 \quad 1050 \quad 1100 \quad 1150$

Fig. 1. MALDI-ToF-MS spectrum of native glycans isolated from OPEFB XOS fraction avDP 4. The glycan adduct ions methylated-glucuronic acid substitution ( $\mathrm{Pent}_{n} \mathrm{MetHex}_{n} \mathrm{Ac}_{\mathrm{n}}$ ) and for hexose oligosaccharides $\left(\mathrm{Hex}_{n}\right)$. 
318 were as follows: avDP 4 (DP 2-9), avDP 7 (DP 3-12), avDP 14 (DP 3-18). The OPEFB

319 fractions were also xylanase cleaved and visualised by polysaccharide analysis using

320 carbohydrate gel electrophoresis (PACE) (Fig.2) which confirms the predominant

321 oligosaccharides were xylo-oligosaccharides and that the gel filtration fractionation of the

322 avDP 4 to avDP 64 contained similar oligosaccharides but with increasing xylose chain

323 length.

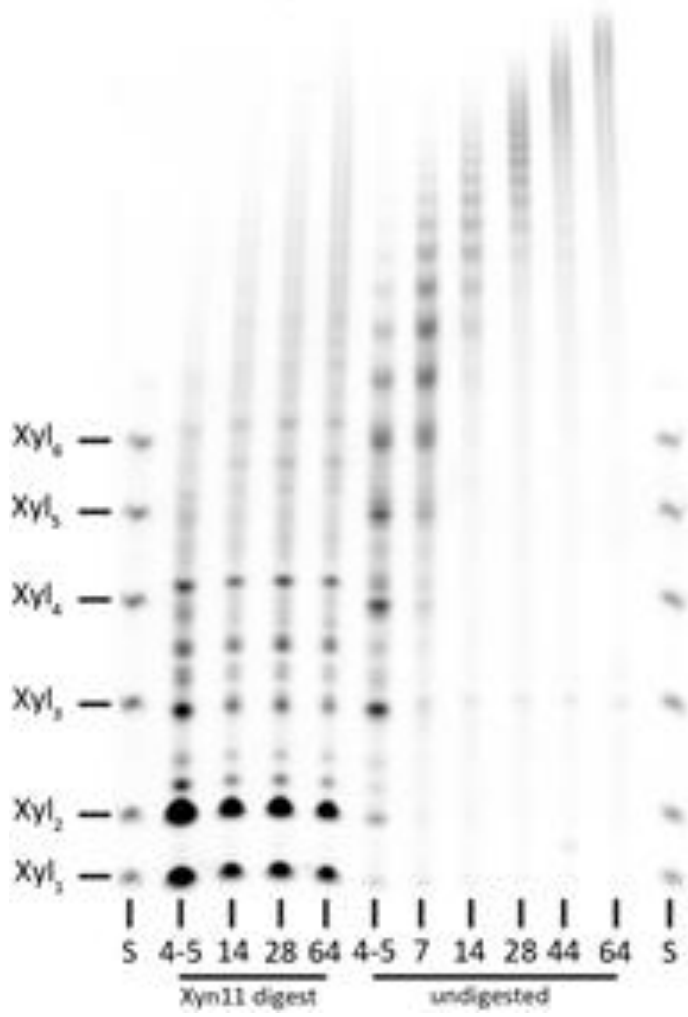

327 Fig. 2. PACE gel showing separation of extracted OPEFB XOS fractions digested with 328 Xyn11 and undigested. S - Standard xylose $e_{1-6}$ ladder; $4-5=\operatorname{avDP} 4 ; 14=\operatorname{avDP} 14 ; 28=$ 329 avDP 28 and $64=$ avDP 64 , digested with Xyn11. 4-5 = avDP 4; $7=\operatorname{avDP} 7 ; 14=\operatorname{avDP}$ $33014 ; 28=\operatorname{avDP} 28 ; 44=\operatorname{avDP} 44$ and $64=\operatorname{avDP} 64$, undigested OPEFB XOS fractions. 
Changes in the bacterial populations during the in vitro fermentations with the

333 different XOS fractions are shown in Table 2. A significant increase $(\mathrm{p}<0.05)$ of

334 Bifidobacterium population, ranging between $0.5-0.8 \log$ cells $/ \mathrm{mL}$ for all time points

335 compared to time $0 \mathrm{~h}$ was observed for the XOS fractions with avDP of 4, 7 and 14,

336 commercial XOS and FOS. In the case of the XOS fractions with avDP of 28 and 44,

337 significant increases $(\mathrm{p}<0.05)$ were observed for the $10 \mathrm{~h}$ sample, whereas for the XOS

338 fraction with avDP of 64, although an increase was observed for the $10 \mathrm{~h}$ sample, this was

339 not statistically significant ( $\mathrm{p} \geq 0.05)$. For all these higher avDP $(28,44,64)$ fractions, the

340 concentrations were sustained for the $24 \mathrm{~h}$ and $36 \mathrm{~h}$ samples and were not statistically

341 different to $0 \mathrm{~h}$. Taking into account the above and the fact that the effect of the XOS

342 fractions with low avDP (avDP 4-14) on the Bifidobacterium population was similar to that

343 of commercial XOS, which mainly consists of DP 2-3, it can be inferred that bifidobacteria

344 preferred the lower molecular weight XOS fractions. This is also supported by the fact that

345 birch wood xylan did not have a significant effect on the Bifidobacterium population. In the

346 pure culture study, there were few strains of Bifidobacterium capable of fermenting high

347 molecular weight XOS or xylan (Palframan, Gibson \& Rastall, 2003b). The reason for the

348 increase in the Bifidobacterium population at $10 \mathrm{~h}$ for the XOS fractions of avDP 14, 28, 44

349 could be that the bifidobacteria utilise the low molecular weight XOS, which were present

350 in the fractions as demonstrated by the MALDI-ToF-MS. Another possibility is that higher

351 molecular weight XOS was hydrolysed to smaller XOS molecules by other microorganisms

352 such as Bacteroides (Chassard, Goumy, Leclerc, Del'homme \& Bernalier-Donadille, 2007; 
Table 2

Mean bacterial populations in $\mathrm{pH}$-controlled batch cultures at $0,10,24$ and $36 \mathrm{~h}^{\mathrm{a}}$

\begin{tabular}{|c|c|c|c|c|c|c|c|c|c|c|}
\hline \multirow[t]{2}{*}{ Probe } & \multirow[t]{2}{*}{ Time $(\mathrm{h})$} & \multicolumn{9}{|c|}{ Bacterial population ( $\log _{10}$ cells/ml batch culture fluid) in substrate } \\
\hline & & $\begin{array}{c}\text { OPEFB XOS } \\
(\text { avDP 4) }\end{array}$ & $\begin{array}{c}\text { OPEFB XOS } \\
(\text { avDP 7) }\end{array}$ & $\begin{array}{c}\text { OPEFB XOS } \\
\text { (avDP 14) }\end{array}$ & $\begin{array}{c}\text { OPEFB XPS } \\
(\text { avDP 28) }\end{array}$ & $\begin{array}{c}\text { OPEFB XPS } \\
(\text { avDP 44) }\end{array}$ & $\begin{array}{c}\text { OPEFB XPS } \\
\text { (avDP 64) }\end{array}$ & $\begin{array}{c}\text { Birch wood } \\
\text { xylan }\end{array}$ & $\begin{array}{c}\text { XOS } \\
(\mathrm{SLBC})\end{array}$ & $\begin{array}{c}\text { FOS } \\
\text { (Raftilose) }\end{array}$ \\
\hline \multirow[t]{2}{*}{ Bif164 } & 10 & $8.38(0.19)^{\mathrm{ab}^{*}}$ & $8.37(0.18)^{\mathrm{ab}^{*}}$ & $8.41(0.27)^{\mathrm{ab}^{*}}$ & $8.31(0.16)^{\mathrm{ab}^{*}}$ & $8.26(0.16)^{\mathrm{ab}^{*}}$ & $8.22(0.10)^{\mathrm{ab}}$ & $8.15(0.10)^{\mathrm{a}}$ & $8.65(0.13)^{b^{6 * *}}$ & $8.64(0.08)^{b^{* * *}}$ \\
\hline & 24 & $8.56(0.14)^{\mathrm{a}^{*}}$ & $8.50(0.19)^{\mathrm{a}^{*}}$ & $8.59(0.16)^{\mathrm{a}^{*}}$ & $8.40(0.29)^{\mathrm{a}}$ & $8.36(0.28)^{\mathrm{a}}$ & $8.29(0.28)^{\mathrm{a}}$ & $8.25(0.29)^{\mathrm{a}}$ & $8.53(0.06)^{\mathrm{a}^{* *}}$ & $8.48(0.12)^{\mathrm{a}^{*}}$ \\
\hline 7.85(0.09) & 36 & $8.41(0.15)^{\mathrm{a}^{*}}$ & $8.46(0.13)^{\mathrm{a}^{*}}$ & $8.54(0.10)^{\mathrm{a}^{* *}}$ & $8.30(0.24)^{\mathrm{a}}$ & $8.24(0.21)^{\mathrm{a}}$ & $8.10(0.21)^{\mathrm{a}}$ & $8.01(0.23)^{\mathrm{a}}$ & $8.38(0.19)^{\mathrm{a}^{*}}$ & $8.31(0.35)^{\mathrm{a}}$ \\
\hline \multirow[t]{2}{*}{ Bac303 } & 10 & $8.58(0.08)^{\mathrm{a}^{*}}$ & $8.62(0.17)^{\mathrm{a}}$ & $8.64(0.27)^{\mathrm{a}}$ & $8.62(0.13)^{\mathrm{a}^{*}}$ & $8.46(0.26)^{\mathrm{a}}$ & $8.43(0.14)^{\mathrm{a}^{*}}$ & $8.48(0.34)^{\mathrm{a}}$ & $8.54(0.11)^{\mathrm{a}}$ & $8.63(0.20)^{\mathrm{a}}$ \\
\hline & 24 & $8.50(0.14)^{\mathrm{a}^{* *}}$ & $8.50(0.06)^{\mathrm{a}^{* *}}$ & $8.71(0.04)^{\mathrm{a}^{*}}$ & $8.59(0.25)^{\mathrm{a}^{*}}$ & $8.50(0.44)^{\mathrm{a}}$ & $8.41(0.50)^{\mathrm{a}}$ & $8.59(0.35)^{\mathrm{a}}$ & $8.42(0.13)^{\mathrm{a}^{*}}$ & $8.46(0.21)^{\mathrm{a}}$ \\
\hline $8.10(0.09)$ & 36 & $8.30(0.17)^{\mathrm{a}}$ & $8.31(0.12)^{\mathrm{a}}$ & $8.46(0.04)^{\mathrm{a}^{* *}}$ & $8.33(0.32)^{\mathrm{a}}$ & $8.43(0.29)^{\mathrm{a}}$ & $8.27(0.46)^{\mathrm{a}}$ & $8.32(0.14)^{\mathrm{a}^{*}}$ & $8.29(0.20)^{\mathrm{a}}$ & $8.15(0.08)^{\mathrm{a}}$ \\
\hline \multirow[t]{2}{*}{ Lab158 } & 10 & $8.30(0.19)^{\mathrm{a}}$ & $8.42(0.25)^{\mathrm{a}}$ & $8.45(0.23)^{a^{*}}$ & $8.45(0.20)^{\mathrm{a}^{*}}$ & $8.38(0.26)^{\mathrm{a}}$ & $8.29(0.05)^{\mathrm{a}^{*}}$ & $8.27(0.14)^{\mathrm{a}}$ & $8.51(0.13)^{\mathrm{a}^{*}}$ & $8.45(0.22)^{\mathrm{a}}$ \\
\hline & 24 & $8.36(0.17)^{\mathrm{a}}$ & $8.50(0.19)^{\mathrm{a}^{*}}$ & $8.57(0.20)^{\mathrm{a}^{*}}$ & $8.46(0.07)^{\mathrm{a}^{* *}}$ & $8.29(0.35)^{\mathrm{a}}$ & $8.24(0.24)^{\mathrm{a}}$ & $8.42(0.19)^{\mathrm{a}^{*}}$ & $8.35(0.14)^{\mathrm{a}^{*}}$ & $8.30(0.15)^{\mathrm{a}^{*}}$ \\
\hline 7.97(0.04) & 36 & $8.31(0.17)^{\mathrm{a}}$ & $8.45(0.12)^{\mathrm{a}^{*}}$ & $8.46(0.14)^{a^{*}}$ & $8.27(0.11)^{\mathrm{a}}$ & $8.10(0.31)^{\mathrm{a}}$ & $8.04(0.32)^{\mathrm{a}}$ & $8.13(0.19)^{\mathrm{a}}$ & $8.28(0.24)^{\mathrm{a}}$ & $8.32(0.35)^{\mathrm{a}}$ \\
\hline \multirow[t]{2}{*}{ Ato291 } & 10 & $8.22(0.03)^{a^{a *}}$ & $8.19(0.05)^{\mathrm{ab}^{*}}$ & $8.12(0.05)^{\mathrm{ab}^{* *}}$ & $8.07(0.18)^{\mathrm{a}}$ & $8.00(0.07)^{\mathrm{a}}$ & $8.05(0.14)^{\mathrm{a}}$ & $7.97(0.32)^{\mathrm{a}}$ & $8.42(0.17)^{a b^{* *}}$ & $8.56(0.20)^{b^{* * *}}$ \\
\hline & 24 & $8.14(0.09)^{\mathrm{bcd} *}$ & $8.08(0.10)^{\mathrm{abc} * *}$ & $7.93(0.11)^{\mathrm{ab}}$ & $7.99(0.03)^{\mathrm{abc} *}$ & $7.87(0.04)^{\mathrm{ab}}$ & $7.72(0.05)^{\mathrm{a}}$ & $8.00(0.20)^{\mathrm{abc}}$ & $8.35(0.20)^{\mathrm{cd} *}$ & $8.51(0.23)^{\mathrm{d}^{* *}}$ \\
\hline $7.78(0.10)$ & 36 & $7.88(0.23)^{\mathrm{abc}}$ & $7.80(0.17)^{\mathrm{ab}}$ & $7.81(0.16)^{\mathrm{ab}}$ & $7.69(0.10)^{\mathrm{a}}$ & $7.60(0.15)^{\mathrm{a}}$ & $7.57(0.15)^{\mathrm{a}}$ & $7.66(0.21)^{\mathrm{a}}$ & $8.22(0.24)^{\mathrm{bc}}$ & $8.37(0.05)^{\mathrm{c}^{* *}}$ \\
\hline \multirow[t]{2}{*}{ Prop853 } & 10 & $7.90(0.04)^{\mathrm{a}^{*}}$ & $8.07(0.12)^{\mathrm{a}}$ & $8.08(0.08)^{\mathrm{a}^{*}}$ & $8.11(0.05)^{\mathrm{a}^{\mathrm{a} *}}$ & $8.05(0.03)^{\mathrm{a}^{* *}}$ & $8.01(0.23)^{\mathrm{a}}$ & $7.92(0.32)^{\mathrm{a}}$ & $7.99(0.23)^{\mathrm{a}}$ & $7.97(0.25)^{\mathrm{a}}$ \\
\hline & 24 & $8.03(0.26)^{\mathrm{a}}$ & $8.12(0.09)^{\mathrm{a}^{*}}$ & $8.17(0.08)^{\mathrm{a}^{*}}$ & $8.13(0.14)^{\mathrm{a}^{*}}$ & $8.04(0.30)^{\mathrm{a}}$ & $7.87(0.37)^{\mathrm{a}}$ & $7.98(0.23)^{\mathrm{a}}$ & $8.02(0.32)^{\mathrm{a}}$ & $7.97(0.37)^{\mathrm{a}}$ \\
\hline $7.71(0.05)$ & 36 & $7.87(0.33)^{\mathrm{a}}$ & $7.92(0.16)^{\mathrm{a}}$ & $7.86(0.19)^{\mathrm{a}}$ & $7.78(0.13)^{\mathrm{a}}$ & $7.74(0.41)^{\mathrm{a}}$ & $7.68(0.41)^{\mathrm{a}}$ & $7.76(0.20)^{\mathrm{a}}$ & $7.61(0.12)^{\mathrm{a}}$ & $7.86(0.24)^{\mathrm{a}}$ \\
\hline \multirow[t]{2}{*}{ Erec482 } & 10 & $8.09(0.20)^{\mathrm{a}}$ & $8.18(0.47)^{\mathrm{a}}$ & $8.28(0.48)^{\mathrm{a}}$ & $8.29(0.37)^{\mathrm{a}}$ & $8.15(0.18)^{\mathrm{a}}$ & $8.20(0.14)^{\mathrm{a}}$ & $8.20(0.18)^{\mathrm{a}}$ & $8.28(0.30)^{\mathrm{a}}$ & $8.31(0.24)^{\mathrm{a}}$ \\
\hline & 24 & $8.26(0.12)^{\mathrm{a}^{*}}$ & $8.44(0.34)^{\mathrm{a}}$ & $8.35(0.51)^{\mathrm{a}}$ & $8.43(0.27)^{a}$ & $8.08(0.52)^{\mathrm{a}}$ & $8.22(0.27)^{\mathrm{a}}$ & $8.24(0.14)^{\mathrm{a}^{*}}$ & $8.36(0.15)^{a^{*}}$ & $8.33(0.08)^{\mathrm{a}^{* *}}$ \\
\hline $7.99(0.04)$ & 36 & $8.43(0.10)^{\mathrm{a}^{*}}$ & $8.41(0.33)^{\mathrm{a}}$ & $8.27(0.47)^{\mathrm{a}}$ & $8.28(0.09)^{\mathrm{a}^{*}}$ & $8.19(0.32)^{\mathrm{a}}$ & $8.13(0.41)^{\mathrm{a}}$ & $8.20(0.33)^{\mathrm{a}}$ & $8.28(0.14)^{a^{*}}$ & $8.14(0.12)^{\mathrm{a}}$ \\
\hline \multirow[t]{2}{*}{ Rrec584 } & 10 & $7.48(0.16)^{\mathrm{a}}$ & $7.48(0.11)^{\mathrm{a}}$ & $7.49(0.18)^{\mathrm{a}}$ & $7.45(0.02)^{\mathrm{a}^{*}}$ & $7.38(0.02)^{\mathrm{a}^{*}}$ & $7.35(0.06)^{\mathrm{a}^{*}}$ & $7.38(0.12)^{\mathrm{a}}$ & $7.52(0.22)^{\mathrm{a}}$ & $7.41(0.17)^{\mathrm{a}}$ \\
\hline & 24 & $7.61(0.06)^{\mathrm{ab}}$ & $7.58(0.11)^{\mathrm{ab}}$ & $7.46(0.19)^{\mathrm{a}}$ & $7.54(0.10)^{a b}$ & $7.51(0.17)^{\mathrm{ab}}$ & $7.50(0.06)^{\mathrm{a}}$ & $7.50(0.15)^{\mathrm{a}}$ & $7.85(0.05)^{b^{*}}$ & $7.76(0.11)^{a^{2 *}}$ \\
\hline 7.38(0.05) & 36 & $7.70(0.22)^{\mathrm{a}^{*}}$ & $7.65(0.15)^{\mathrm{a}}$ & $7.65(0.21)^{\mathrm{a}}$ & $7.53(0.07)^{\mathrm{a}^{*}}$ & $7.59(0.20)^{\mathrm{a}}$ & $7.60(0.12)^{\mathrm{a}}$ & $7.40(0.20)^{\mathrm{a}}$ & $7.87(0.20)^{a^{*}}$ & $7.75(0.15)^{\mathrm{a}}$ \\
\hline \multirow[t]{2}{*}{ Fprau655 } & 10 & $7.58(0.26)^{\mathrm{a}}$ & $7.67(0.29)^{\mathrm{a}}$ & $7.66(0.30)^{\mathrm{a}}$ & $7.72(0.13)^{a}$ & $7.61(0.19)^{\mathrm{a}}$ & $7.62(0.13)^{\mathrm{a}}$ & $7.65(0.30)^{\mathrm{a}}$ & $7.53(0.26)^{\mathrm{a}}$ & $7.67(0.34)^{\mathrm{a}}$ \\
\hline & 24 & $7.36(0.08)^{\mathrm{a}}$ & $7.45(0.11)^{\mathrm{a}}$ & $7.57(0.24)^{\mathrm{a}}$ & $7.84(0.10)^{\mathrm{a}^{*}}$ & $7.51(0.27)^{\mathrm{a}}$ & $7.58(0.22)^{\mathrm{a}}$ & $7.74(0.27)^{\mathrm{a}}$ & $7.49(0.20)^{\mathrm{a}}$ & $7.60(0.22)^{\mathrm{a}}$ \\
\hline 7.54(0.10) & 36 & $7.44(0.24)^{\mathrm{a}}$ & $7.46(0.02)^{\mathrm{a}}$ & $7.47(0.21)^{\mathrm{a}}$ & $7.56(0.19)^{\mathrm{a}}$ & $7.40(0.11)^{\mathrm{a}^{*}}$ & $7.55(0.27)^{\mathrm{a}}$ & $7.48(0.28)^{\mathrm{a}}$ & $7.34(0.12)^{\mathrm{a}}$ & $7.43(0.25)^{\mathrm{a}}$ \\
\hline \multirow[t]{2}{*}{ Chis150 } & 10 & $7.41(0.21)^{\mathrm{a}}$ & $7.48(0.09)^{\mathrm{a}}$ & $7.44(0.13)^{\mathrm{a}}$ & $7.49(0.10)^{\mathrm{a}}$ & $7.38(0.07)^{\mathrm{a}}$ & $7.38(0.15)^{\mathrm{a}}$ & $7.44(0.09)^{\mathrm{a}}$ & $7.36(0.11)^{\mathrm{a}}$ & $7.56(0.27)^{\mathrm{a}}$ \\
\hline & 24 & $7.34(0.04)^{\mathrm{a}}$ & $7.34(0.15)^{\mathrm{a}}$ & $7.23(0.06)^{\mathrm{a}}$ & $7.31(0.10)^{\mathrm{a}}$ & $7.27(0.05)^{\mathrm{a}}$ & $7.24(0.07)^{\mathrm{a}}$ & $7.36(0.09)^{\mathrm{a}}$ & $7.28(0.03)^{\mathrm{a}}$ & $7.34(0.12)^{\mathrm{a}}$ \\
\hline 7.33(0.05) & 36 & $6.93(0.12)^{\mathrm{a}}$ & $6.97(0.08)^{\mathrm{a}^{*}}$ & $6.95(0.15)^{\mathrm{a}}$ & $6.91(0.06)^{\mathrm{a}^{*}}$ & $6.90(0.16)^{\mathrm{a}}$ & $6.71(0.07)^{\mathrm{a}^{*}}$ & $6.95(0.15)^{\mathrm{a}^{*}}$ & $6.88(0.08)^{\mathrm{a}^{*}}$ & $6.80(0.06)^{\mathrm{a}^{*}}$ \\
\hline \multirow[t]{2}{*}{ Eub338 } & 10 & $9.17(0.11)^{\mathrm{a}}$ & $9.21(0.12)^{\mathrm{a}^{*}}$ & $9.22(0.10)^{\mathrm{a}^{*}}$ & $9.19(0.06)^{\mathrm{a}^{*}}$ & $9.16(0.15)^{\mathrm{a}}$ & $9.10(0.10)^{\mathrm{a}^{*}}$ & $9.06(0.14)^{\mathrm{a}}$ & $9.33(0.18)^{a}$ & $9.30(0.11)^{\mathrm{a}^{*}}$ \\
\hline & 24 & $9.25(0.17)^{\mathrm{a}}$ & $9.25(0.10)^{\mathrm{a}^{*}}$ & $9.30(0.14)^{\mathrm{a}^{*}}$ & $9.25(0.13)^{\mathrm{a}^{*}}$ & $9.24(0.18)^{\mathrm{a}}$ & $9.12(0.13)^{\mathrm{a}}$ & $9.12(0.16)^{\mathrm{a}}$ & $9.27(0.16)^{\mathrm{a}}$ & $9.18(0.11)^{\mathrm{a}}$ \\
\hline $8.79(0.06)$ & 36 & $9.16(0.19)^{\mathrm{a}}$ & $9.15(0.15)^{\mathrm{a}}$ & $9.22(0.13)^{\mathrm{a}}$ & $9.08(0.05)^{\mathrm{a}^{*}}$ & $9.08(0.34)^{\mathrm{a}}$ & $8.93(0.33)^{\mathrm{a}}$ & $8.91(0.19)^{\mathrm{a}}$ & $9.09(0.17)^{\mathrm{a}}$ & $9.06(0.13)^{\mathrm{a}}$ \\
\hline
\end{tabular}

${ }^{\text {a} S t a n d a r d ~ d e v i a t i o n ~ i s ~ s h o w n ~ i n ~ p a r e n t h e s e s ~}(n=3)$. Significant differences $(\mathrm{p}<0.05)$ between substrates are indicated with different letters in a same row.

"Significant differences from value at $0 \mathrm{~h}, \mathrm{p}<0.05$; ${ }^{* *}$ Significant differences from value at $0 \mathrm{~h}, \mathrm{p}<0.01$ (Value at $0 \mathrm{~h}$ is shown in the far left under 'Probe' column) 353 
354 Falony, Calmeyn, Leroy \& De Vuyst, 2009). This was also observed in studies carried out 355 by Mäkeläinen and co-workers (2010a; 2010b), a high molecular weight xylan (DP 35-40) 356 was not efficiently metabolised by a range of Bifidobacterium strains in pure culture studies

357 but when they tested the same xylan in a semi continuous colon simulator system using 358 faecal inoculum, they observed a significant increase in the Bifidobacterium sp. population. 359 Another bacterial group which had significant difference between substrates is the 360 Atopobium cluster. Atopobium has the highest count on FOS, significantly higher $(\mathrm{p}<0.05)$ 361 than OPEFB XOS of avDP 28, 44 and 64. These results are consistent with Hughes et al. 362 (2007) whereby the large molecular weight AXOS (278 kDa and $354 \mathrm{kDa})$ generally did 363 not induce growth of Atopobium.

369 Acetate and propionate concentration on the other hand continued to rise up to $24 \mathrm{~h}$ and/or $37036 \mathrm{~h}$, whereas butyrate, though present at low concentration initially, increased steadily up 371 to $36 \mathrm{~h}$.

All OPEFB XOS produced significantly lower $(\mathrm{p}<0.05)$ amount of lactate than

373 commercial XOS and FOS. The wider DP distribution and possibility the presence of 374 substituents on OPEFB XOS may affect the accessibility for bifidobacterial fermentation. 375 Kabel et al. (2002a) also observed a higher amount of lactate in non-substituted XOS than 
376 substituted XOS. According to Falony et al. (2009), metabolism in bifidobacteria produces

377 more formate, acetate and ethanol at the expense of lactate when there is limited access to

378 substrate. Different carbohydrates are known to promote the growth of different species of

379 bifidobacteria, resulting in varying amount of lactate (Palframan et al., 2003b).

380 The initial acetate level in OPEFB XOS avDP 4 was high, possibly as a result of

381 free acetic acid present in the low molecular weight substrate. XOS in all OPEFB fractions

382 and the commercial XOS resulted in higher acetate and less propionate and butyrate than

383 FOS. This typical profile corresponds with previous studies conducted on XOS and xylan

384 fermentation (Englyst, Hay \& Macfarlane, 1987; Kabel et al., 2002a; Rycroft, Jones,

385 Gibson \& Rastall, 2001). 
386

Table 3

Mean organic acid concentrations in $\mathrm{pH}$-controlled batch cultures at $0,10,24$ and $36 \mathrm{~h}^{\mathrm{a}}$

\begin{tabular}{|c|c|c|c|c|c|c|c|c|c|c|}
\hline \multirow{2}{*}{$\begin{array}{l}\text { Organic } \\
\text { acid }\end{array}$} & \multirow{2}{*}{$\begin{array}{l}\text { Time } \\
\text { (h) }\end{array}$} & \multicolumn{9}{|c|}{ Concentration (mM) } \\
\hline & & $\begin{array}{c}\text { OPEFB XOS } \\
\text { (avDP 4) }\end{array}$ & $\begin{array}{c}\text { OPEFB XOS } \\
\text { (avDP 7) }\end{array}$ & $\begin{array}{c}\text { OPEFB XOS } \\
\text { (avDP 14) }\end{array}$ & $\begin{array}{c}\text { OPEFB XPS } \\
\text { (avDP 28) }\end{array}$ & $\begin{array}{c}\text { OPEFB XPS } \\
\text { (avDP 44) }\end{array}$ & $\begin{array}{c}\text { OPEFB XPS } \\
\text { (avDP 64) }\end{array}$ & $\begin{array}{l}\text { Birch wood } \\
\text { xylan }\end{array}$ & XOS (Suntory) & FOS (Raftilose) \\
\hline \multirow[t]{4}{*}{ Lactate } & 0 & $0.00(0.00)^{\mathrm{a}}$ & $0.00(0.00)^{\mathrm{a}}$ & $0.00(0.00)^{\mathrm{a}}$ & $0.00(0.00)^{\mathrm{a}}$ & $0.00(0.00)^{\mathrm{a}}$ & $0.00(0.00)^{\mathrm{a}}$ & $0.00(0.00)^{\mathrm{a}}$ & $0.78(0.68)^{\mathrm{a}}$ & $0.79(0.68)^{\mathrm{a}}$ \\
\hline & 10 & $4.88(2.92)^{\mathrm{a}}$ & $1.85(2.32)^{\mathrm{a}}$ & $2.46(2.38)^{\mathrm{a}}$ & $0.81(1.40)^{\mathrm{a}}$ & $2.34(1.44)^{\mathrm{a}}$ & $0.46(0.79)^{\mathrm{a}}$ & $0.79(0.72)^{\mathrm{a}}$ & $16.11(5.89)^{\mathrm{b}^{*}}$ & $19.29(6.34)^{\mathrm{b}^{*}}$ \\
\hline & 24 & $0.56(0.98)^{\mathrm{a}}$ & $0.32(0.56)^{\mathrm{a}}$ & $1.02(1.76)^{\mathrm{a}}$ & $0.00(0.00)^{\mathrm{a}}$ & $0.50(0.87)^{\mathrm{a}}$ & $0.00(0.00)^{\mathrm{a}}$ & $0.32(0.56)^{\mathrm{a}}$ & $0.00(0.00)^{\mathrm{a}}$ & $0.00(0.00)^{\mathrm{a}}$ \\
\hline & 36 & $0.00(0.00)^{\mathrm{a}}$ & $0.00(0.00)^{\mathrm{a}}$ & $0.00(0.00)^{\mathrm{a}}$ & $0.00(0.00)^{\mathrm{a}}$ & $0.45(0.78)^{\mathrm{a}}$ & $0.00(0.00)^{\mathrm{a}}$ & $0.47(0.81)^{\mathrm{a}}$ & $0.00(0.00)^{\mathrm{a}}$ & $0.00(0.00)^{\mathrm{a}}$ \\
\hline \multirow[t]{4}{*}{ Formate } & 0 & $0.58(0.04)^{\mathrm{d}}$ & $0.16(0.07)^{\mathrm{bc}}$ & $0.11(0.07)^{\mathrm{abc}}$ & $0.11(0.06)^{\mathrm{abc}}$ & $0.13(0.06)^{\mathrm{abc}}$ & $0.36(0.04)^{\mathrm{a}}$ & $0.16(0.03)^{\mathrm{c}}$ & $0.03(0.04)^{\mathrm{ab}}$ & $0.01(0.01)^{\mathrm{a}}$ \\
\hline & 10 & $8.42(8.28)^{\mathrm{a}}$ & $7.61(7.02)^{\mathrm{a}}$ & $4.26(5.39)^{\mathrm{a}}$ & $8.37(6.06)^{\mathrm{a}}$ & $4.11(5.44)^{\mathrm{a}}$ & $5.80(7.78)^{\mathrm{a}}$ & $2.64(1.64)^{\mathrm{a}}$ & $14.06(3.49)^{\mathrm{a}^{*}}$ & $14.96(5.90)^{\mathrm{a}^{*}}$ \\
\hline & 24 & $5.33(3.65)^{\mathrm{a}}$ & $5.66(8.32)^{\mathrm{a}}$ & $3.54(6.12)^{\mathrm{a}}$ & $4.26(7.38)^{\mathrm{a}}$ & $6.44(5.58)^{\mathrm{a}}$ & $2.19(3.56)^{\mathrm{a}}$ & $0.05(0.08)^{\mathrm{a}}$ & $6.56(5.94)^{\mathrm{a}}$ & $1.69(2.86)^{\mathrm{a}}$ \\
\hline & 36 & $0.00(0.00)^{\mathrm{a}}$ & $1.93(3.34)^{\mathrm{a}}$ & $0.55(0.95)^{\mathrm{a}}$ & $0.00(0.00)^{\mathrm{a}}$ & $2.34(2.54)^{\mathrm{a}}$ & $0.00(0.00)^{\mathrm{a}}$ & $0.00(0.00)^{\mathrm{a}}$ & $1.24(2.15)^{\mathrm{a}}$ & $0.00(0.00)^{\mathrm{a}}$ \\
\hline Acetate & 0 & $10.08(2.41)^{\mathrm{c}}$ & $6.70(1.79)^{\mathrm{bc}}$ & $6.00(1.56)^{\mathrm{b}}$ & $5.62(1.72)^{\mathrm{ab}}$ & $5.20(0.50)^{\mathrm{ab}}$ & $5.18(0.38)^{\mathrm{ab}}$ & $5.84(0.06)^{\mathrm{ab}}$ & $2.18(0.03)^{\mathrm{a}}$ & $2.31(0.30)^{\mathrm{a}}$ \\
\hline \multirow[t]{3}{*}{ (A) } & 10 & $48.44(21.23)^{\mathrm{a}}$ & $47.45(24.27)^{\mathrm{a}}$ & $47.84(23.12)^{\mathrm{a}}$ & $51.72(24.48)^{\mathrm{a}}$ & $33.12(22.07)^{\mathrm{a}}$ & $37.19(27.31)^{\mathrm{a}}$ & $25.53(6.71)^{\mathrm{a}^{*}}$ & $54.82(8.47)^{\mathrm{a}^{* *}}$ & $47.55(11.02)^{\mathrm{a}^{*}}$ \\
\hline & 24 & $77.39(21.26)^{\mathrm{b}^{*}}$ & $71.61(7.48)^{\mathrm{ab}^{* *}}$ & $78.37(6.57)^{\mathrm{b}^{* *}}$ & $62.35(11.82)^{\mathrm{ab}^{*}}$ & $57.30(28.36)^{\mathrm{ab}}$ & $43.50(26.36)^{\mathrm{ab}}$ & $28.98(7.96)^{\mathrm{a}^{*}}$ & $60.19(2.00)^{\mathrm{ab}^{* *}}$ & $43.10(6.47)^{\mathrm{ab} \mathrm{b}^{* *}}$ \\
\hline & 36 & $79.80(22.19)^{\mathrm{b}^{*}}$ & $68.68(10.00)^{\mathrm{ab}^{* *}}$ & $78.70(6.86)^{\mathrm{b}^{* *}}$ & $54.60(10.09)^{\mathrm{ab}^{*}}$ & $59.49(27.07)^{\mathrm{ab}}$ & $41.44(30.12)^{\mathrm{ab}}$ & $21.32(7.03)^{\mathrm{a}}$ & $60.53(3.77)^{\mathrm{ab}^{* *}}$ & $39.61(7.66)^{\mathrm{ab}^{*}}$ \\
\hline Propionate & 0 & $3.08(0.52)^{\mathrm{a}}$ & $2.75(0.19)^{\mathrm{a}}$ & $2.69(0.18)^{\mathrm{a}}$ & $2.67(0.19)^{\mathrm{a}}$ & $2.70(0.10)^{\mathrm{a}}$ & $2.69(0.22)^{\mathrm{a}}$ & $2.76(0.18)^{\mathrm{a}}$ & $2.61(0.11)^{\mathrm{a}}$ & $2.67(0.42)^{\mathrm{a}}$ \\
\hline \multirow{3}{*}{ (P) } & 10 & $9.23(4.64)^{\mathrm{a}}$ & $13.84(10.69)^{\mathrm{a}}$ & $15.60(11.96)^{\mathrm{a}}$ & $12.77(1.82)^{\mathrm{a}^{*}}$ & $7.96(1.94)^{\mathrm{a}^{*}}$ & $11.37(6.05)^{\mathrm{a}}$ & $10.28(2.78)^{\mathrm{a}^{*}}$ & $13.28(8.04)^{\mathrm{a}}$ & $15.55(14.71)^{\mathrm{a}}$ \\
\hline & 24 & $16.57(4.75)^{\mathrm{a}^{*}}$ & $20.10(7.20)^{\mathrm{a}}$ & $25.10(8.72)^{\mathrm{a}^{*}}$ & $18.43(2.87)^{\mathrm{a}^{*}}$ & $18.15(10.37)^{\mathrm{a}}$ & $11.46(10.51)^{\mathrm{a}}$ & $13.22(4.72)^{\mathrm{a}}$ & $18.07(8.97)^{\mathrm{a}}$ & $18.58(16.11)^{\mathrm{a}}$ \\
\hline & 36 & $17.93(5.55)^{\mathrm{a}^{*}}$ & $18.82(6.41)^{\mathrm{a}^{*}}$ & $25.70(7.51)^{\mathrm{a}^{*}}$ & $16.35(2.54)^{\mathrm{a}^{*}}$ & $19.27(11.63)^{\mathrm{a}}$ & $11.28(11.08)^{\mathrm{a}}$ & $9.91(3.20)^{\mathrm{a}}$ & $17.96(9.82)^{\mathrm{a}}$ & $18.22(16.91)^{\mathrm{a}}$ \\
\hline Butyrate & 0 & $0.00(0.00)^{\mathrm{a}}$ & $0.00(0.00)^{\mathrm{a}}$ & $0.00(0.00)^{\mathrm{a}}$ & $0.00(0.00)^{\mathrm{a}}$ & $0.00(0.00)^{\mathrm{a}}$ & $0.00(0.00)^{\mathrm{a}}$ & $0.00(0.00)^{\mathrm{a}}$ & $0.00(0.00)^{\mathrm{a}}$ & $0.00(0.00)^{\mathrm{a}}$ \\
\hline \multirow{3}{*}{ (B) } & 10 & $1.11(1.72)^{\mathrm{a}}$ & $1.85(1.84)^{\mathrm{a}}$ & $1.87(2.33)^{\mathrm{a}}$ & $2.08(1.47)^{\mathrm{a}}$ & $1.11(1.44)^{\mathrm{a}}$ & $1.89(1.06)^{\mathrm{a}}$ & $1.76(0.86)^{\mathrm{a}}$ & $1.89(1.65)^{\mathrm{a}}$ & $2.68(1.08)^{\mathrm{a}^{*}}$ \\
\hline & 24 & $2.99(1.81)^{\mathrm{a}}$ & $3.08(2.13)^{\mathrm{a}}$ & $3.32(3.40)^{\mathrm{ab}}$ & $3.67(1.74)^{\mathrm{ab}}$ & $1.66(1.46)^{\mathrm{a}}$ & $2.66(2.48)^{\mathrm{a}}$ & $3.39(1.92)^{\mathrm{ab}}$ & $11.41(5.31)^{\mathrm{bc}}$ & $13.16(3.29)^{\mathrm{c}^{*}}$ \\
\hline & 36 & $4.07(1.75)^{\mathrm{ab}}$ & $3.52(2.31)^{\mathrm{a}}$ & $4.49(4.11)^{\mathrm{ab}}$ & $4.09(1.03)^{\mathrm{ab}^{*}}$ & $2.40(2.02)^{\mathrm{a}}$ & $3.24(3.60)^{\mathrm{a}}$ & $3.09(2.79)^{\mathrm{a}}$ & $12.30(4.64)^{\mathrm{bc} *}$ & $13.23(2.49)^{\mathrm{c}^{*}}$ \\
\hline \multirow[t]{4}{*}{ Total } & 0 & $13.73(2.70)^{\mathrm{b}}$ & $9.61(1.85)^{\mathrm{ab}}$ & $8.80(1.65)^{\mathrm{a}}$ & $8.40(1.87)^{\mathrm{a}}$ & $8.04(0.42)^{\mathrm{a}}$ & $8.23(0.56)^{\mathrm{a}}$ & $8.77(0.22)^{\mathrm{a}}$ & $5.59(0.67)^{\mathrm{a}}$ & $5.77(1.38)^{\mathrm{a}}$ \\
\hline & 10 & $72.09(29.09)^{\mathrm{a}}$ & $72.60(33.75)^{\mathrm{a}}$ & $72.03(32.92)^{\mathrm{a}}$ & $75.74(32.56)^{\mathrm{a}}$ & $48.64(27.61)^{\mathrm{a}}$ & $56.71(41.11)^{\mathrm{a}}$ & $41.00(11.33)^{\mathrm{a}^{*}}$ & $100.15(7.69)^{\mathrm{a}^{* *}}$ & $100.03(1.46)^{\mathrm{a}^{* *}}$ \\
\hline & 24 & $102.84(27.40)^{\mathrm{a}^{*}}$ & $100.77(7.09)^{\mathrm{a}^{* *}}$ & $111.35(6.55)^{\mathrm{a}^{* *}}$ & $88.71(21.28)^{\mathrm{a}^{*}}$ & $84.05(44.15)^{\mathrm{a}}$ & $59.80(42.27)^{\mathrm{a}}$ & $45.97(13.62)^{\mathrm{a}^{*}}$ & $96.24(4.10)^{\mathrm{a}^{* *}}$ & $76.52(10.92)^{\mathrm{a}^{* * *}}$ \\
\hline & 36 & $101.80(26.14)^{\mathrm{ab}^{*}}$ & $92.95(6.64)^{\mathrm{ab} * *}$ & $109.44(2.12)^{\mathrm{b}^{* *}}$ & $75.04(12.69)^{\mathrm{ab}^{*}}$ & $83.96(41.10)^{\mathrm{ab}}$ & $55.95(44.40)^{\mathrm{ab}}$ & $34.79(12.76)^{\mathrm{a}}$ & $92.03(7.57)^{\mathrm{ab}^{* *}}$ & $71.05(17.60)^{\mathrm{ab}^{*}}$ \\
\hline \multirow[t]{4}{*}{$\mathrm{A}: \mathrm{P}: \mathrm{B}$} & 0 & $1: 0.3: 0$ & $1: 0.4: 0$ & $1: 0.5: 0$ & $1: 0.5: 0$ & $1: 0.5: 0$ & $1: 0.5: 0$ & $1: 0.5: 0$ & $1: 1.2: 0$ & $1: 1.2: 0$ \\
\hline & 10 & 1:0.2:0.03 & 1:0.3:0.03 & $1: 0.3: 0.03$ & 1:0.3:0.04 & 1:0.3:0.04 & 1:0.3:0.06 & 1:0.4:0.07 & 1:0.3:0.03 & 1:0.4:0.06 \\
\hline & 24 & 1:0.2:0.04 & 1:0.3:0.04 & $1: 0.3: 0.04$ & 1:0.3:0.06 & 1:0.3:0.04 & 1:0.3:0.06 & $1: 0.5: 0.1$ & $1: 0.3: 0.2$ & $1: 0.5: 0.3$ \\
\hline & 36 & 1:0.2:0.05 & 1:0.3:0.05 & 1:0.3:0.06 & 1:0.3:0.08 & $1: 0.3: 0.05$ & 1:0.3:0.06 & $1: 0.5: 0.1$ & $1: 0.3: 0.2$ & $1: 0.5: 0.4$ \\
\hline
\end{tabular}

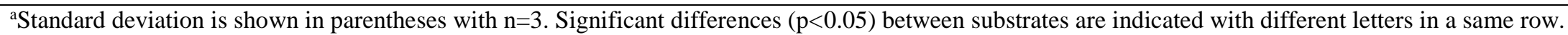

*Increased significantly from value at $0 \mathrm{~h}, \mathrm{p}<0.05 ;{ }^{* *}$ Increased significant differences from value at $0 \mathrm{~h}, \mathrm{p}<0.01$ 
can be linked to the two major acetate producers; Bifidobacterium spp. and the BacteroidesPrevotella group.

There was no significant increase in butyrate on any OPEFB XOS while

391 commercial XOS resulted in similar butyrate level to FOS ( $\mathrm{p} \geq 0.05)$. Nevertheless, the XOS

392 preparation of lower avDP $(4,14,28)$ were not different to commercial XOS $(\mathrm{p} \geq 0.05)$.

393 Although the human gut microbiota has also been known to be able to further metabolise

394 acetate to butyrate (Duncan, Barcenilla, Stewart, Pryde \& Flint, 2002; Duncan et al., 2004),

395 the conversion of acetate from OPEFB XOS to butyrate was generally lower.

396 The type and molecular weight of the substrates influenced rate and amount of

397 organic acid produced. Based on total organic acid, it is noticeable that commercial XOS

398 and FOS were the fastest fermentable substrates, reaching at least $100 \mathrm{mM}$ at $10 \mathrm{~h}$. As for

399 OPEFB XOS, the three lowest $\operatorname{avDP}(4,7,14)$ reached $100 \mathrm{mM}$ at $24 \mathrm{~h}$ while other

400 fractions of higher avDP $(28,44,64)$ had less than $100 \mathrm{mM}$ and birch wood xylan, the least

401 fermentable substrate had the lowest organic acid of all with $46 \mathrm{mM}$ at $24 \mathrm{~h}$.

402

403 3.4 Carbohydrate assimilation profile during fermentation

404 The carbohydrate was profiled in the samples during the course of fermentation using

405 HPAEC-PAD to observe the changes in DP. The assimilation profile of OPEFB XOS of 406 avDP14 from each faecal donor is illustrated in Fig. 3. The three donors showed slight

407 variation in magnitudes and trends that coincides with rather high standard deviation

408 observed in the organic acid data. At $10 \mathrm{~h}$, donor 1 XOS were utilised faster, leaving behind 
409 xylose. For donor 2, since the rate of fermentation is slower, some oligosaccharides were 410 still present at $10 \mathrm{~h}$ and without much increase of xylose. Donor 3 had a trend between

411 donor 1 and 2 whereby the XOS were also quickly fermented and broken down into xylose, 412 xylobiose and xylotriose. At $24 \mathrm{~h}$ there was no detectable sugar remaining in all the culture 413 samples. While the xylose and low DP XOS were being consumed by the bacteria,

414 accumulation could arise from continual digestion of XOS/XPS from the higher DP. This

415 similar degradation characteristic was also observed in XOS (DP 2-6) derived from rice

416 husk when fermented with a single bifidobacteria culture (Gullón et al., 2008).

417 Analysis with HPAEC-PAD however does not provide information on acetyl groups 418 as deacetylation occurs in the high pH eluent used in HPAEC (Kabel et al., 2002a). As such, 419 the chromatogram could not show the susceptibility of acetylated XOS during fermentation. 420 
a



Donor 1

$\mathrm{b}$

.

d

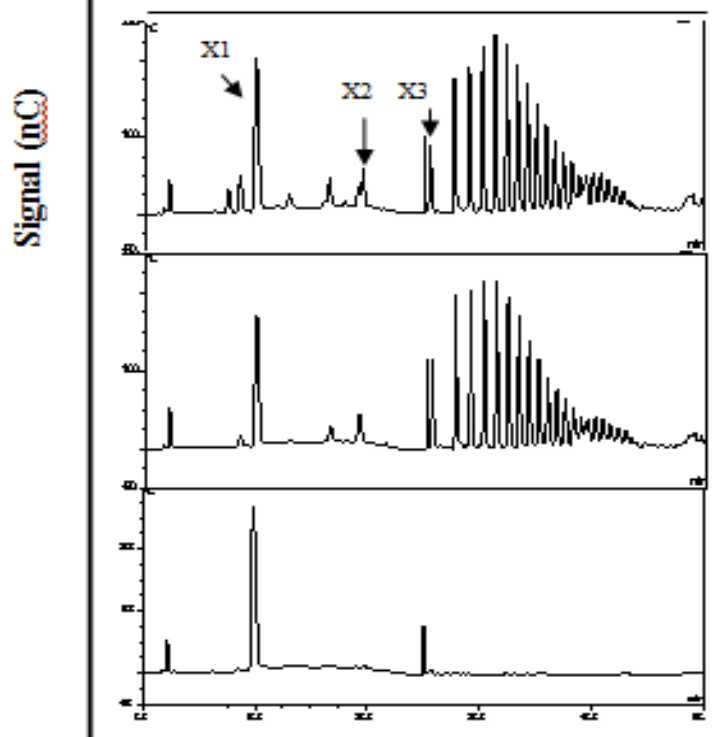

Donor 2

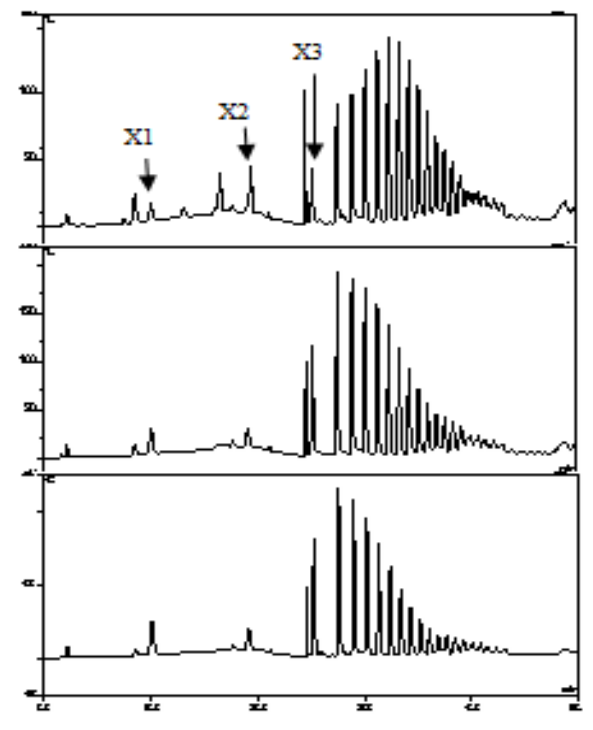

Donor 3



Time (min)

Fig. 3. Degradation profile of OPEFB XOS avDP 14 at different time by faecal culture from three donors using HPAEC-PAD: (a) Substrate before fermentation, (b) Immediately after substrate addition into fermenter, (c) After 5 h, (d) After 10 h. X1, X2, $\mathrm{X} 3$ on the chromatogram indicate the position of xylose, xylobiose and xylotriose, respectively. 


\section{Conclusion}

The solubility of high avDP XOS/XPS preparation from OPEFB through

427 autohydrolysis process is rather interesting as it could be incorporated into many food

428 processes. The acetyl group may aid XOS/XPS solubility, however the impact of this on

429 fermentation in the gut was not conclusive from the present results. Nevertheless, the

430 degree of polymerisation has significant influence on OPEFB XOS/XPS fermentability by

431 the gut microflora. The in vitro study conducted in this work shows the low avDP XOS (4,

$4327,14)$ were more selective to beneficial bacteria than the higher avDP XPS $(22,44,64)$.

433 OPEFB XOS fractions of avDP 14 appeared to be the most bifidogenic.

\section{Acknowledgements}

436 This work was supported by Malaysian Ministry of Higher Education for funding a

437 scholarship to Ai Ling Ho. The XOS fractions used in this study was produced using the

438 facilities provided at Bioenergy Unit, LNEG, Portugal. Rothamsted Research receives

439 grant-aided support from the Biotechnology and Biological Sciences Research Council

440 (BBSRC) of the UK.

\section{References}

443 Campbell, J. M., Fahey, J., George C., \& Wolf, B. W. (1997). Selected indigestible

444 oligosaccharides affect large bowel mass, cecal and fecal short-chain fatty acids, $\mathrm{pH}$

445 and microflora in rats. The Journal of Nutrition, 127, 130-136. 
Chassard, C., Goumy, V., Leclerc, M., Del'homme, C., \& Bernalier-Donadille, A. (2007). Characterization of the xylan-degrading microbial community from human faeces. FEMS Microbiology Ecology, 61, 121-131.

Childs, C. E., Roytio, H., Alhoniemi, E., Fekete, A. A., Forssten, S. D., Hudjec, N., Lim, Y. N., Steger, C. J., Yaqoob, P., Tuohy, K. M., Rastall, R. A., Ouwehand, A. C., \& Gibson, G. R. (2014). Xylo-oligosaccharides alone or in synbiotic combination with Bifidobacterium animalis subsp. lactis induce bifidogenesis and modulate markers of immune function in healthy adults: A double-blind, placebo-controlled, randomised, factorial cross-over study. British Journal of Nutrition, 111, 1945-1956.

Chung, Y.-C., Hsu, C.-K., Ko, C.-Y., \& Chan, Y.-C. (2007). Dietary intake of xylooligosaccharides improves the intestinal microbiota, fecal moisture, and $\mathrm{pH}$ value in the elderly. Nutrition Research, 27, 756-761.

Ciucanu, I., \& Kerek, F. (1984). A simple and rapid method for the permethylation of carbohydrates. Carbohydrate Research, 131, 209-217.

Crittenden, R., Karppinen, S., Ojanen, S., Tenkanen, M., Fagerström, R., Mättö, J., Saarela, M., Mattila-Sandholm, T., \& Poutanen, K. (2002). In vitro fermentation of cereal dietary fibre carbohydrates by probiotic and intestinal bacteria. Journal of the Science of Food and Agriculture, 82, 781-789.

Daims, H., Brühl, A., Amann, R., Schleifer, K.-H., \& Wagner, M. (1999). The domainspecific probe EUB338 is insufficient for the detection of all bacteria: Development and evaluation of a more comprehensive probe set. Systematic and Applied Microbiology, 22, 434-444. 
Duncan, S. H., Barcenilla, A., Stewart, C. S., Pryde, S. E., \& Flint, H. J. (2002). Acetate utilization and butyryl coenzyme A (CoA):Acetate-CoA transferase in butyrateproducing bacteria from the human large intestine. Applied and Environmental Microbiology, 68, 5186-5190.

Duncan, S. H., Holtrop, G., Lobley, G. E., Calder, A. G., Stewart, C. S., \& Flint, H. J. (2004). Contribution of acetate to butyrate formation by human faecal bacteria. British Journal of Nutrition, 91, 915-923.

Ebringerová, A., Hromadkova, Z., \& Heinze, T. (2005). Polysaccharides I: Structure, characterization and use. Advances In Polymer Science, 186, 1-67.

Englyst, H. N., Hay, S., \& Macfarlane, G. T. (1987). Polysaccharide breakdown by mixed populations of human faecal bacteria. FEMS Microbiology Letters, 45, 163-171.

Falony, G., Calmeyn, T., Leroy, F., \& De Vuyst, L. (2009). Coculture fermentations of Bifidobacterium species and Bacteroides thetaiotaomicron reveal a mechanistic insight into the prebiotic effect of inulin-type fructans. Applied and Environmental Microbiology, 75, 2312-2319.

Franks, A. H., Harmsen, H. J. M., Raangs, G. C., Jansen, G. J., Schut, F., \& Welling, G. W. (1998). Variations of bacterial populations in human feces measured by fluorescent in situ hybridization with group-specific $16 \mathrm{~S}$ rRNA-targeted oligonucleotide probes. Applied and Environmental Microbiology, 64, 3336-3345.

Gullón, P., Moura, P., Esteves, M. P., Girio, F. M., Domínguez, H., \& Parajó, J. C. (2008). Assessment on the fermentability of xylooligosaccharides from rice husks by probiotic bacteria. Journal of Agricultural and Food Chemistry, 56, 7482-7487. 
Harmsen, H. J. M., Elfferich, P., Schut, F., \& Welling, G. W. (1999). A 16S rRNA-targeted probe for detection of lactobacilli and enterococci in faecal samples by fluorescent in situ hybridization. Microbial Ecology in Health and Disease, 11, 3-12.

Harmsen, H. J. M., Wildeboer-Veloo, A. C. M., Grijpstra, J., Knol, J., Degener, J. E., \& Welling, G. W. (2000). Development of 16S rRNA-based probes for the Coriobacterium group and the Atopobium cluster and their application for enumeration of Coriobacteriaceae in human feces from volunteers of different age groups. Applied and Environmental Microbiology, 66, 4523-4527.

Ho, A. L., Carvalheiro, F., Duarte, L. C., Roseiro, L. B., Charalampopoulos, D., \& Rastall, R. A. (2014). Production and purification of xylooligosaccharides from oil palm empty fruit bunch fibre by a non-isothermal process. Bioresource Technology, 152, 526-529.

Hold, G. L., Schwiertz, A., Aminov, R. I., Blaut, M., \& Flint, H. J. (2003). Oligonucleotide probes that detect quantitatively significant groups of butyrate-producing bacteria in human feces. Applied and Environmental Microbiology, 69, 4320-4324.

Hughes, S. A., Shewry, P. R., Li, L., Gibson, G. R., Sanz, M. L., \& Rastall, R. A. (2007). In vitro fermentation by human fecal microflora of wheat arabinoxylans. Journal of Agricultural and Food Chemistry, 55, 4589-4595.

Kabel, M. A., Kortenoeven, L., Schols, H. A., \& Voragen, A. G. J. (2002a). In vitro fermentability of differently substituted xylo-oligosaccharides. Journal of Agricultural and Food Chemistry, 50, 6205-6210. 
511 Kabel, M. A., Schols, H. A., \& Voragen, A. G. J. (2002b). Complex xylo-oligosaccharides

512 identified from hydrothermally treated Eucalyptus wood and brewery's spent grain.

513 Carbohydrate Polymers, 50, 191-200.

514 Kosik, O., Bromley, J. R., Busse-Wicher, M., Zhang, Z., and Dupree, P. (2012). Studies of

515 enzymatic cleavage of cellulose using polysaccharide analysis by carbohydrate gel

516 electrophoresis (PACE). Methods in Enzymology, 510, 51-67.

517 Langendijk, P. S., Schut, F., Jansen, G. J., Raangs, G. C., Kamphuis, G. R., Wilkinson, M.

518 H., \& Welling, G. W. (1995). Quantitative fluorescence in situ hybridization of

519 Bifidobacterium spp. with genus-specific $16 \mathrm{~S}$ rRNA-targeted probes and its

$520 \quad$ application in fecal samples. Applied and Environmental Microbiology, 61, 3069-

$521 \quad 3075$.

522 Mäkeläinen, H., Forssten, S., Saarinen, M., Stowell, J., Rautonen, N., \& Ouwehand, A. C.

523 (2010a). Xylo-oligosaccharides enhance the growth of bifidobacteria and

524 Bifidobacterium lactis in a simulated colon model. Beneficial Microbes, 1, 81-91.

525 Mäkeläinen, H., Saarinen, M., Stowell, J., Rautonen, N., \& Ouwehand, A. C. (2010b).

526 Xylo-oligosaccharides and lactitol promote the growth of Bifidobacterium lactis and

527 Lactobacillus species in pure cultures. Beneficial Microbes, 1, 139-148.

528 Manz, W., Amann, R., Ludwig, W., Vancanneyt, M., \& Schleifer, K.-H. (1996).

529 Application of a suite of $16 \mathrm{~S}$ rRNA-specific oligonucleotide probes designed to

530 investigate bacteria of the phylum cytophaga-flavobacter-bacteroides in the natural

531 environment. Microbiology, 142, 1097-1106.

532 Marsh, J. T., Tryfona, T., Powers, S. J., Stephens, E., Dupree, P., Shewry, P. R., \&

533 Lovegrove, A. (2011). Determination of the N-glycosylation patterns of seed 
proteins: Applications to determine the authenticity and substantial equivalence of genetically modified (GM) crops. Journal of Agricultural and Food Chemistry, 59, 8779-8788.

Moura, P., Barata, R., Carvalheiro, F., Gírio, F., Loureiro-Dias, M. C., \& Esteves, M. P. (2007). In vitro fermentation of xylo-oligosaccharides from corn cobs autohydrolysis by Bifidobacterium and Lactobacillus strains. LWT - Food Science and Technology, 40, 963-972.

Moure, A., Gullón, P., Domínguez, H., \& Parajó, J. C. (2006). Advances in the manufacture, purification and applications of xylo-oligosaccharides as food additives and nutraceuticals. Process Biochemistry, 41, 1913-1923.

Nabarlatz, D., Ebringerová, A., \& Montané, D. (2007). Autohydrolysis of agricultural byproducts for the production of xylo-oligosaccharides. Carbohydrate Polymers, 69 , 20-28.

Okazaki, M., Fujikawa, S., \& Matsumoto, N. (1990). Effect of xylooligosaccharide on the growth of bifidobacteria. Bifidobacteria and Microflora, 9, 77-86.

Palframan, R., Gibson, G. R., \& Rastall, R. A. (2003a). Development of a quantitative tool for the comparison of the prebiotic effect of dietary oligosaccharides. Letters in Applied Microbiology, 37, 281-284.

Palframan, R. J., Gibson, G. R., \& Rastall, R. A. (2003b). Carbohydrate preferences of Bifidobacterium species isolated from human gut. Current Issues in Intestinal Microbiology, 4, 71-75. 
555 Parajó, J. C., Garrote, G., Cruz, J. M., \& Domínguez, H. (2004). Production of

556 xylooligosaccharides by autohydrolysis of lignocellulosic materials. Trends in Food $557 \quad$ Science and Technology, 15, 115-120.

558 Rycroft, C. E., Jones, M. R., Gibson, G. R., \& Rastall, R. A. (2001). A comparative in vitro 559 evaluation of the fermentation properties of prebiotic oligosaccharides. Journal of $560 \quad$ Applied Microbiology, 91, 878-887.

561 Singleton, V. L., \& Rossi, J. A. J. (1965). Colorimetry of total phenolics with 562 phosphomolybdic-phosphotungstic acid reagents. American Journal of Enology and $563 \quad$ Viticulture, 16, 144-158.

564 Sluiter, A., Hames, B., Ruiz, R., Scarlata, C., Sluiter, J., \& Templeton, D. (2006).

565 Determination of sugars, by-products, and degradation products in liquid fraction 566 process samples. Laboratory Analytical Procedure (NREL/TP-510-42623). Colorado: $567 \quad$ National Renewable Energy Laboratory.

568 Van Craeyveld, V., Swennen, K., Dornez, E., Van de Wiele, T., Marzorati, M., Verstraete, 569 W., Delaedt, Y., Onagbesan, O., Decuypere, E., Buyse, J., De Ketelaere, B., F. 570 Broekaert, W., Delcour, J. A., \& Courtin, C. M. (2008). Structurally different wheat571 derived arabinoxylooligosaccharides have different prebiotic and fermentation 572 properties in rats. The Journal of Nutrition, 138, 2348-2355.

573 Walker, A. W., Duncan, S. H., McWilliam Leitch, E. C., Child, M. W., \& Flint, H. J.

574 (2005). pH and peptide supply can radically alter bacterial populations and short575 chain fatty acid ratios within microbial communities from the human colon. Applied 576 and Environmental Microbiology, 71, 3692-3700. 